Supporting Information for

\title{
CanE, an Iron/2-Oxoglutarate-dependent Lasso Peptide Hydroxylase from Streptomyces canus
}

Chen Zhang ${ }^{\dagger}$ and Mohammad R. Seyedsayamdost*,t,‡

†Department of Chemistry, Princeton University, Princeton, NJ 08544

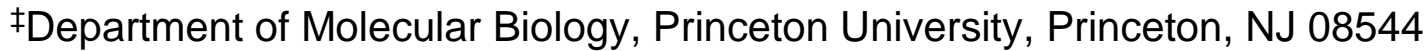

*Correspondence: mrseyed@princeton.edu 


\section{Materials and Routine Culture Media}

LB broth, LB-agar, tryptic soy broth, peptone, malt extract, casamino acids, and yeast extract were purchased from Beckton Dickinson. TES, L-valine, PMSF, Trizma base, imidazole, TEV protease, $\alpha-K G$, sodium ascorbate, all primers, all reagents for solid phase peptide synthesis, and all antibiotics, with the exception of apramycin, were obtained from SigmaAldrich. Apramycin, L-proline, glycerol, agarose, and casein acid hydrolysate were purchased from Fisher Scientific. Q5 DNA polymerase, Taq DNA polymerase, restriction enzymes, T4 ligase, trypsin and the corresponding buffers were obtained from New England Biolabs. Nickel affinity resin and IPTG were from Clontech and UBPBio, respectively. NutriSoy ${ }^{\circledR}$ soy flour was obtained from Genesee. Miniprep and gel extraction kits were ordered from Qiagen. The following media were routinely used to culture $S$. canus: YEME medium: $10.7 \%(\mathrm{w} / \mathrm{v})$ sucrose, $0.3 \%(\mathrm{w} / \mathrm{v})$ yeast extract, $0.5 \%(\mathrm{w} / \mathrm{v})$ peptone, $0.3 \%(\mathrm{w} / \mathrm{v})$ malt extract, $1 \%(\mathrm{w} / \mathrm{v})$ glucose. TSBY medium: $3 \%(\mathrm{w} / \mathrm{v})$ tryptone soy broth and $0.5 \%(\mathrm{w} / \mathrm{v})$ yeast extract. R4 medium: $0.5 \%(\mathrm{w} / \mathrm{v})$ glucose, $0.1 \%(\mathrm{w} / \mathrm{v})$ yeast extract, $0.15 \%(\mathrm{w} / \mathrm{v})$ proline, $0.118 \%(\mathrm{w} / \mathrm{v})$ valine, $0.005 \%(\mathrm{w} / \mathrm{v})$ casomino acids, $0.5 \%(\mathrm{w} / \mathrm{v}) \mathrm{MgCl}_{2} \cdot 6 \mathrm{H}_{2} \mathrm{O}, 0.2 \%(\mathrm{w} / \mathrm{v}) \mathrm{CaCl}_{2} \cdot 2 \mathrm{H}_{2} \mathrm{O}, 0.28 \%(\mathrm{w} / \mathrm{v}) \mathrm{TES}, 0.01 \%(\mathrm{w} / \mathrm{v})$ potassium sulfate, $0.1 \%(\mathrm{v} / \mathrm{v})$ trace element solution $\left(40 \mathrm{mg} / \mathrm{L} \mathrm{ZnCl} 2,200 \mathrm{mg} / \mathrm{L} \mathrm{FeCl}{ }_{3} \cdot 6 \mathrm{H}_{2} \mathrm{O}, 10\right.$ $\mathrm{mg} / \mathrm{L} \quad \mathrm{CuCl}_{2} \cdot 2 \mathrm{H}_{2} \mathrm{O}, 10 \mathrm{mg} / \mathrm{L} \quad \mathrm{MnCl}_{2} \cdot 4 \mathrm{H}_{2} \mathrm{O}, 10 \mathrm{mg} / \mathrm{L} \quad \mathrm{Na}_{2} \mathrm{~B}_{4} \mathrm{O}_{7} \cdot 10 \mathrm{H}_{2} \mathrm{O}, 10 \mathrm{mg} / \mathrm{L}$ $\left.\left(\mathrm{NH}_{4}\right)_{6} \mathrm{Mo}_{7} \mathrm{O}_{24} \bullet 4 \mathrm{H}_{2} \mathrm{O}\right), \mathrm{pH}=7.0$. SFM agar medium was prepared by dissolving $2 \%(\mathrm{w} / \mathrm{v})$ soybean meal in tap water, followed by autoclave-sterilization and filtration through cheese cloths. The filtrate was then supplemented with $2 \%(\mathrm{w} / \mathrm{v})$ mannitol and $2 \%(\mathrm{w} / \mathrm{v})$ agar, and autoclaved again.

\section{Bacterial strains and plasmids}

Streptomyces canus NRRL B-3980 was obtained from the ARS (NRRL) culture collection. E. coli strain ET12567, and plasmids plJ773 and pJTU1289 were kindly provided by the Deng lab at Shanghai Jiao Tong University.

\section{Creation of gene inactivation mutants in S. canus}

Generation of the knock-out plasmid for the CanE::apr insertional mutant. Genomic DNA of $S$. canus was extracted using the Wizard ${ }^{\circledR}$ Genomic DNA Purification Kit (Promega). Two kb fragments upstream and downstream of canE were PCR-amplified using Q5 or Taq DNA polymerase and the corresponding primers (Table S1). PCR products were purified via gel extraction, and digested with Spel/EcoRI (upstream) and HindIII/Kpnl (downstream). The 773_cassette fragment (Apr resistance gene apr fused to oriT) was obtained through EcoRI/Hindlll digestion of the vector plJ773. Vector pJTU1289 was digested with Spel/Kpnl. All digested fragments (canE downstream and upstream fragments, 773_cassette and pJTU1289) were purified by gel extraction and ligated by T4 DNA ligase under room temperature for 2 hours. Ligation products were chemically transformed into E. coli $\mathrm{DH} 5 \alpha$ cells, which was plated on LB agar supplemented with Amp $(100 \mu \mathrm{g} / \mathrm{mL})$ and Apr $(50 \mu \mathrm{g} / \mathrm{mL})$. Single colonies were picked and grown in LB medium containing Amp $(100 \mu \mathrm{g} / \mathrm{mL})$ and Apr $(50 \mu \mathrm{g} / \mathrm{mL})$ for the isolation of plasmid pCZ006 (canE KO plasmid).

Generation of the knock-out plasmid for the CanC::apr insertional mutant. A $\sim 2 \mathrm{~kb}$ fragment upstream and a $\sim 2 \mathrm{~kb}$ fragment downstream of canC were PCR-amplified using Q5 DNA polymerase and the corresponding primers (Table S1). PCR products were purified through gel extraction, and digested with Sacl/Xbal (upstream) and Spel/HindIII (downstream). 
773_cassette_Spel fragment was amplified by PCR using primers 773_Spel_for and 773_Spel_rev, purified by gel extraction and digested with Spel. Vector pJTU1289 was digested with Sacl/HindlII. All digested fragments (canC downstream and upstream fragments, 773_cassette_Spel and pJTU1289) were purified by gel extraction and ligated by T4 DNA ligase at room temperature for 2 hours. Ligation products were chemically transformed into $E$. coli $\mathrm{DH} 5 \alpha$ cells, which were plated on LB agar supplemented with Amp (100 $\mu \mathrm{g} / \mathrm{mL})$ and Apr (50 $\mu \mathrm{g} / \mathrm{mL})$. Single colonies were picked and grown in LB medium containing Amp (100 $\mu \mathrm{g} / \mathrm{mL})$ and Apr $(50 \mu \mathrm{g} / \mathrm{mL})$ for the isolation of plasmid pCZ007 (canC KO plasmid).

Conjugation. $\mathrm{KO}$ plasmids $\left(\mathrm{Amp}^{\mathrm{R}}, \mathrm{Apr}^{\mathrm{R}}, \mathrm{Tsr}^{\mathrm{R}}\right)$ were separately transformed into chemically competent E. coli ET12567 $\left(\mathrm{Cm}^{\mathrm{R}}\right)$, which carries the mobilizing vector pUZ8002 $\left(\mathrm{Kan}^{\mathrm{R}}\right)$. E. coli ET12567 strain carrying the $\mathrm{KO}$ plasmid was cultured in $25 \mathrm{~mL}$ of LB medium supplemented with Amp (100 $\mu \mathrm{g} / \mathrm{mL})$, Apr $(50 \mu \mathrm{g} / \mathrm{mL})$, Kan $(50 \mu \mathrm{g} / \mathrm{mL})$ and $\mathrm{Cm}(25 \mu \mathrm{g} / \mathrm{mL})$ to an $\mathrm{OD}_{600}$ of $0.5-0.7$. Cells were collected by centrifugation $(4000 \mathrm{~g}, 10 \mathrm{~min})$, washed with $\mathrm{LB}(10 \mathrm{~mL}$, twice) to remove antibiotics, and resuspended in $500 \mu \mathrm{L}$ of LB medium for later use.

Spores of $S$. canus for were grown on two $25 \mathrm{~mL}$ SFM agar plates and collected into water using cotton swabs. Spores were centrifuged (8000 rpm, $5 \mathrm{~min})$, washed with $1 \mathrm{~mL}$ of TES buffer ( $50 \mathrm{mM}, \mathrm{pH} 8.0$ ), resuspended in $500 \mu \mathrm{L}$ of TES buffer, and heat-shocked at $45^{\circ} \mathrm{C}$ for 10 min. After heat-shock, spores were ice-bathed for $1 \mathrm{~min}$, supplemented with 2x-spore activation buffer [1\% (w/v) yeast extract, $1 \%(\mathrm{w} / \mathrm{v})$ casein hydrolysate acid, $5 \mathrm{mM} \mathrm{CaCl}_{2}$, and incubated at $37^{\circ} \mathrm{C} / 200 \mathrm{rpm}$ for 3 hours. Spores were collected by centrifugation (8000 rpm, $5 \mathrm{~min}$ ), resuspended in $500 \mu \mathrm{L}$ of LB medium, and mixed with 100-200 $\mu \mathrm{L}$ of the LB suspension of the E. coli ET12567 donor strain (see above). The mixture was plated on SFM agar plate and incubated at $30{ }^{\circ} \mathrm{C}$ for $20-24$ hours. Exconjugants were then selected with Apr $(50 \mu \mathrm{g} / \mathrm{mL})$ and trimethoprim (Tmp, $50 \mu \mathrm{g} / \mathrm{mL}$ ) (to kill donor $E$. coli). After incubation at $30^{\circ} \mathrm{C}$ for $4-7$ days, single colonies were picked for validation and grown on SFM agar plate containing Apr $(50 \mu \mathrm{g} / \mathrm{mL})$ and $\operatorname{Tmp}(50 \mu \mathrm{g} / \mathrm{mL})$. Then exconjugant colonies were cultured at $30^{\circ} \mathrm{C} / 250 \mathrm{rpm}$ for 3 days in TSBY medium containing Apr and Tmp at the same concentrations. For selection of double-crossover mutants, exconjugant culture was inoculated into antibiotic-free YEME medium. The surviving cells were sub-cultured again in antibiotic-free YEME medium. After growth of 2-3 days, the cultures were diluted and plated on SFM agar plates to obtain single colonies. Single colonies were then individually tested on SFM agar plates for Tsr-susceptibility and Apr-resistance. Double-crossover mutants that were resistant to Apr and susceptible to Tsr were cultured and subsequently validated using PCR (Figures S1-S2).

\section{Fermentation of wt, $\triangle$ canC, and $\triangle$ canE S. canus}

Frozen stocks of wt and $S$. canus mutants were streaked out on SFM agar plates. After 3-day incubation at $30^{\circ} \mathrm{C}$, the same amount of mycelium from each strain was inoculated into 14 $\mathrm{mL}$ culture tubes containing $3 \mathrm{~mL}$ of TSBY medium and cultured at $30^{\circ} \mathrm{C} / 250 \mathrm{rpm}$ for 2 days. Mycelial cells were collected by centrifugation (6000 rpm, $3 \mathrm{~min}$ ) and inoculated into $50 \mathrm{~mL}$ of R4 medium (in a 250-mL Erlenmeyer flask) with a final concentration of $0.05 \%(w / v)$. Kenpaullone was added to the medium at a final concentration of $5.6 \mu \mathrm{g} / \mathrm{mL}$. The cultures were grown at $30^{\circ} \mathrm{C} / 250 \mathrm{rpm}$ for 6 days. Subsequently, cultures were extracted with ethyl acetate (1:1) 
supplemented with formic acid $(0.1 \% \mathrm{v} / \mathrm{v})$. The organic phases were dried in vacuo and resuspend in methanol for HPLC-MS analysis.

\section{Cloning of CanA, CanE, CanB1, and CanB2}

Genes canA and canE were amplified by PCR using Q5 DNA polymerase and primers CanA_for/CanA_rev and CanE_for/CanE_rev. PCR products were confirmed on an agarose gel and purified using via gel extraction.

The canA gene fragment and vector plJ7-NusA were separately digested with $\mathrm{BamHI} / \mathrm{Xhol}$. Digested fragments were purified by gel extraction and ligated by T4 DNA ligase at room temperature for 2 hours. Then the ligation mixture was chemically transformed into $E$. coli $\mathrm{DH} 5 \alpha$ cells. Colonies carrying ligated plasmid plJ7-NusA-canA were selected on LB agar plate (100 $\mu \mathrm{g} / \mathrm{mL}$ Amp). A single colony was grown in LB/Amp $(100 \mu \mathrm{g} / \mathrm{mL})$, the plasmid isolated using a Miniprep Kit (Qiagen), and successful incorporation of canA gene into vector PIJ7-NusA validated first with PCR using primers CanA_for/CanA_rev, and later via DNA sequencing using T7-terminator primers.

The amplified canE gene was directly ligated with EcoRV-digested pBluescript SK(-) using T4 DNA ligase at room temperature for 2 hours. The ligation mixture was chemically transformed into E. coli DH5 $\alpha$ cells, which were plated on LB agar with $100 \mu \mathrm{g} / \mathrm{mL}$ Amp, 40 $\mu \mathrm{g} / \mathrm{mL}$ X-Gal, and $0.2 \mathrm{mg} / \mathrm{mL}$ IPTG. Cells were incubated overnight at $37^{\circ} \mathrm{C}$ and white colonies were picked and cultured for amplification and isolation of the pBluescriptSK(-)-canE. Vectors pBluescriptSK(-)-canE and pET-28b(+) were separately digested with Xhol/Ndel. Digested canE and $\mathrm{pET}-28 \mathrm{~b}(+)$ fragments were purified through gel extraction and ligated by T4 DNA ligase at room temperature for 2 hours. Then the ligation mixture was chemically transformed into $E$. coli $\mathrm{DH} 5 \alpha$ cells. Colonies carrying plasmid pET-28b(+)-canE were selected on LB agar (Kan, 500 $\mu \mathrm{g} / \mathrm{mL})$. Single colonies were picked and grown in LB medium containing Kan $(50 \mu \mathrm{g} / \mathrm{mL})$ for validation. Plasmids were isolated through miniprep and analytic digestion was performed with Xhol and Ndel. The sequence of the canE fragment was confirmed using T7-terminator primers.

canB1 and canB2 gene fragments were amplified by PCR using Q5 DNA polymerase and primers CanB1_for/CanB1_rev and CanB2_for/CanB2_rev, respectively. canB1 and canB2 were cloned into pET-28b(+) and plJ-NusA plasmids, respectively, following the same procedure described above, except that different restriction enzymes were used: Ndel/Hindlll for pET-28b(+)-canB1 and EcoRI/Xhol for plJ7-NusA-canB2.

\section{CanA site-mutagenesis}

DNA fragments containing mutations at Asp14 were PCR-amplified using plJ7-NusAcanA as template, primers CanA_for and CanA_D14X_rev ( $\mathrm{X}=\mathrm{A}, \mathrm{E}, \mathrm{N}, \mathrm{S})$, and Q5 DNA polymerase. The same digestion and ligation procedure described above was used to construct plJ7-NusA-canA_D14X plasmids.

\section{Expression of CanE}

A $14 \mathrm{~mL}$ culture tube containing $5 \mathrm{~mL} \mathrm{LB} / \mathrm{Kan}(50 \mu \mathrm{g} / \mathrm{mL})$ was inoculated with a single colony of $E$. coli BL21 carrying pET-28b(+)-CanE, grown overnight at $37^{\circ} \mathrm{C} / 200 \mathrm{rpm}$, and then used to inoculate a $250 \mathrm{~mL}$ Erlenmeyer flask containing $50 \mathrm{~mL} \mathrm{LB} / \mathrm{Kan}(50 \mu \mathrm{g} / \mathrm{mL})$. After overnight growth at $37^{\circ} \mathrm{C} / 200 \mathrm{rpm}$, the culture was used to inoculate Erlenmeyer flasks $(4 \mathrm{~L})$ containing $800 \mathrm{~mL} \mathrm{LB} / \mathrm{Kan}(50 \mu \mathrm{g} / \mathrm{mL})$ to a starting $\mathrm{OD}_{600}$ of 0.04 . The large cultures were 
grown at $37^{\circ} \mathrm{C} / 180 \mathrm{rpm}$ to an $\mathrm{OD}_{600}$ of $\sim 0.7$, cooled to room temperature, and induced with IPTG ( $1 \mathrm{mM}$ final concentration). They were then grown at $18^{\circ} \mathrm{C} / 180 \mathrm{rpm}$ for $20 \mathrm{~h}$. Cells were harvested by centrifugation $\left(4^{\circ} \mathrm{C}, 5000 \mathrm{rpm}, 10 \mathrm{~min}\right)$, frozen, and stored at $-80^{\circ} \mathrm{C}$ for future use.

\section{Expression of NusA-CanA and variants}

A $14 \mathrm{~mL}$ culture tube containing $5 \mathrm{~mL} \mathrm{LB} / \mathrm{Amp}(100 \mu \mathrm{g} / \mathrm{mL})$ was inoculated with a single E. coli BL21 colony carrying plJ7-NusA-CanA or mutant plasmids. The cultures were grown overnight at $37^{\circ} \mathrm{C} / 200 \mathrm{rpm}$, then used to inoculate a $250 \mathrm{~mL}$ Erlenmeyer flask containing $50 \mathrm{~mL}$ LB/Amp $(100 \mu \mathrm{g} / \mathrm{mL})$. After overnight growth, Erlenmeyer flasks $(4 \mathrm{~L})$ containing $800 \mathrm{~mL}$ $\mathrm{LB} / \mathrm{Amp}(100 \mu \mathrm{g} / \mathrm{mL})$ were inoculated to a starting $\mathrm{OD}_{600}$ of 0.04 . The large cultures were grown at $37^{\circ} \mathrm{C} / 180 \mathrm{rpm}$ to an $\mathrm{OD}_{600}$ of $\sim 0.7$, cooled to room temperature, induced with IPTG ( $1 \mathrm{mM}$ final concentration), followed by growth at $18^{\circ} \mathrm{C} / 180 \mathrm{rpm}$ for 20 hours. Cells were then harvested by centrifugation $\left(4^{\circ} \mathrm{C}, 5000 \mathrm{rpm}, 10 \mathrm{~min}\right)$, frozen, and stored at $-80^{\circ} \mathrm{C}$ for future use.

\section{Expression of CanB1}

E. coli BL21-DE3 cells were chemically transformed with $\mathrm{pET}-28 \mathrm{~b}(+)$-canB1 to generate the overproducing strain. A $14 \mathrm{~mL}$ culture tube containing $5 \mathrm{~mL} \mathrm{LB} / \mathrm{Kan}(50 \mu \mathrm{g} / \mathrm{mL})$ was inoculated with a single E. coli BL21/pET-28b(+)-CanB1, and the culture grown overnight at $37^{\circ} \mathrm{C} / 200 \mathrm{rpm}$. The overnight culture was used to inoculate a $250 \mathrm{~mL}$ Erlenmeyer flask containing $50 \mathrm{~mL} / \operatorname{Kan}(50 \mu \mathrm{g} / \mathrm{mL})$, which was grown overnight and used to inoculated Erlenmeyer flasks $(4 \mathrm{~L})$ containing $800 \mathrm{~mL}$ of $\mathrm{LB} / \mathrm{Kan}\left(50 \mu \mathrm{gL} \mathrm{mL}^{-1}\right)$ to a starting $\mathrm{OD}_{600}$ of 0.04 . The large cultures were grown at $37^{\circ} \mathrm{C} / 180 \mathrm{rpm}$ to an $\mathrm{OD}_{600}$ of $\sim 0.7$, cooled to room temperature, induced with IPTG ( $1 \mathrm{mM}$ final concentration), and cultured for $20 \mathrm{~h}$ at $18^{\circ} \mathrm{C} / 180 \mathrm{rpm}$. Cells were harvested by centrifugation $\left(4^{\circ} \mathrm{C}, 5000 \mathrm{rpm}, 10 \mathrm{~min}\right)$, frozen, and stored at $-80^{\circ} \mathrm{C}$ for future use.

\section{Expression of NusA-CanB2}

plJ7-NusA-canB2 was chemically transformed into E. coli BL21 and NusA-CanB2 was expressed using the same procedure as described above for NusA-CanA.

\section{Protein purification}

The purification of all enzymes was carried out in a cold room at $4^{\circ} \mathrm{C}$. Cell pellets $(\sim 5 \mathrm{~g})$ were resuspended in $30 \mathrm{~mL}$ of lysis buffer $(25 \mathrm{mM}$ Tris, $300 \mathrm{mM} \mathrm{NaCl}, 10 \mathrm{mM}$ imidazole, $10 \%$ glycerol, $\mathrm{pH}$ 7.7) in a $50 \mathrm{~mL}$ falcon tube, and supplemented with PMSF (1 mM final concentration). The suspension was homogenized and sonicated on ice for $5 \mathrm{~min}$ in 5 -s on/15-s off cycles at $35 \%$ power. Cell debris was removed by centrifugation $\left(4^{\circ} \mathrm{C}, 12000 \mathrm{rpm}, 60 \mathrm{~min}\right)$, and the supernatant loaded onto a Ni-affinity column $(5 \mathrm{~mL})$, which had been equilibrated with lysis buffer. The column was washed with $10 \mathrm{CV}$ of lysis buffer and $10 \mathrm{CV}$ of wash buffer (25 $\mathrm{mM}$ Tris, $300 \mathrm{mM} \mathrm{NaCl}, 50 \mathrm{mM}$ imidazole, $10 \%$ glycerol, $\mathrm{pH}$ 7.7). Target proteins were eluted with 5-10 CV of elution buffer ( $25 \mathrm{mM}$ Tris, $300 \mathrm{mM} \mathrm{NaCl}, 300 \mathrm{mM}$ imidazole, $10 \%$ glycerol, $\mathrm{pH}$ 7.7). Fractions were analyzed by SDS-PAGE and those containing the target proteins were pooled, concentrated, and buffer-exchanged into storage buffer $(25 \mathrm{mM}$ Tris, $150 \mathrm{mM} \mathrm{NaCl}, 10 \%$ glycerol, $\mathrm{pH}$ 7.7) using Ultra-filters (Amicon). Concentrated protein aliquots were then flashfrozen in liquid $\mathrm{N}_{2}$ and stored in $-80^{\circ} \mathrm{C}$. A typical yield was $0.5 \mu \mathrm{mol}$ of protein per $\mathrm{L}$ culture. 


\section{CanE reconstitution and assays}

A typical CanE reconstitution/assay was carried out in a total volume of $100 \mu \mathrm{L}$ and contained $\sim 20 \mu \mathrm{M}$ of purified CanE, $1 \mathrm{mM}$ of sodium ascorbate, $250 \mu \mathrm{M}$ of $\alpha$-ketoglutarate and $125 \mu \mathrm{M}$ of ammonium ferrous sulfate in storage buffer. The mixture was incubated on ice for 30 min. Then substrates $(\sim 40 \mu \mathrm{M})$ were added and the mixture was incubated at $30^{\circ} \mathrm{C}$ for $12 \mathrm{~h}$. For NusA-tagged peptide assays, reaction mixtures were directed digested with trypsin (400 $\mathrm{ng}$ ) in the presence of calcium chloride $(20 \mathrm{mM})$. Digestion was performed at $37^{\circ} \mathrm{C}$ for $8 \mathrm{~h}$ before quenching with the addition of $250 \mu \mathrm{L} \mathrm{MeOH}$. Precipitated proteins were removed by centrifugation $(21,000 \mathrm{~g}, 10 \mathrm{~min})$, the supernatants concentrated in vacuo, and the resulting residual resuspended in $\mathrm{MeOH}$ for HR-HPLC-MS analysis. For untagged peptide assays, the reaction mixtures were quenched with the addition of $\mathrm{MeOH}$. Precipitated proteins were removed by centrifugation, the supernatant dried, and resuspended in $\mathrm{MeOH}$ for $\mathrm{HR}$ or LRHPLC-MS analysis.

\section{NusA-CanB2 assays}

A full reaction mixture of $100 \mu \mathrm{L}$ contained storage buffer, NusA-CanB2 ( 12 $\mu \mathrm{M})$, NusACanA $(\sim 40 \mu \mathrm{M})$, CanB1 $(\sim 40 \mu \mathrm{M})$ and $\mathrm{MgCl}_{2}(10 \mathrm{mM})$. Control assays were performed in the absence of CanB1 or heat-inactivated NusA-CanB2 $\left(95^{\circ} \mathrm{C}\right.$ for $\left.15 \mathrm{~min}\right)$. Reactions were incubated at $30^{\circ} \mathrm{C}$ for 3 hours, and then quenched with $200 \mu \mathrm{L}$ of $\mathrm{MeOH}$. Denatured proteins were removed by centrifugation at $21,000 \mathrm{~g}$ for $10 \mathrm{~min}$, and supernatant subjected to HPLCHRMS analysis.

\section{General HR-HPLC-MS analysis}

High resolution HPLC-MS and tandem HPLC-MS analyses were performed on a 6540 UHD Accurate Mass Q-tof LC-MS system (Agilent), consisting of a 1260 Infinity Series HPLC system, an automated liquid sampler, a diode array detector, a JetStream ESI source, and the 6540 Series Q-tof, using an analytical Luna C18 column (Phenomenex, $5 \mu \mathrm{m}, 4.6 \times 100 \mathrm{~mm}$ ) operating at $0.5 \mathrm{~mL} / \mathrm{min}$ with a gradient of $10 \% \mathrm{MeCN}$ in $\mathrm{H}_{2} \mathrm{O}(+0.1 \% \mathrm{FA})$ to $95 \% \mathrm{MeCN}$ in $\mathrm{H}_{2} \mathrm{O}$ $(+0.1 \% \mathrm{FA})$ over $15 \mathrm{~min}$.

\section{Preparation of GS-CanA}

To obtain GS-CanA, a $5 \mathrm{~mL}$ large-scale digestion was carried out with NusA-CanA in storage buffer. The digestion mixture contained $80 \mathrm{mg}$ of purified NusA-CanA protein, TEV protease (2000 units) and dithiothreitol $(1 \mathrm{mM})$. The mixture was incubated at $30^{\circ} \mathrm{C}$ for $12 \mathrm{~h}$, before being quenched with the addition of $10 \mathrm{MeOH}$. Denatured proteins were removed by centrifugation $(21,000 \mathrm{~g}, 10 \mathrm{~min})$. The supernatant containing GS-CanA was concentrated in a speedvac, quantified, and then used directly in CanE assays without further purification.

\section{Synthesis of CanA-core peptide}

The CanA core 14mer peptide was prepared by Fmoc-based solid phase peptide synthesis (SPPS) on an $\mathrm{H}$-Asp(OtBu)-HMPB-ChemMatrix® resin using a Liberty Blue automated peptide synthesizer equipped with a Discover microwave module. The synthesis was conducted on a $0.1 \mathrm{mmol}$ scale, commencing with $0.222 \mathrm{~g}$ of resin. Fmoc-protected amino acids were dissolved in DMF to a concentration of $0.2 \mathrm{M}$. The activator solution consisted of $0.5 \mathrm{M}$ DIC ( $N, N$ '-diisopropyl-carbodiimide) in DMF. The activator base solution consisted of $1 \mathrm{M}$ 
Oxyma and 0.1 M DIPEA ( $N, N^{\prime}$-diisopropylethylamine) in DMF. The deprotection solution consisted of $10 \%(\mathrm{w} / \mathrm{v})$ piperazine in a 10:90 solution of EtOH:NMP ( $N$-methylpyrrolidine) supplemented with $0.1 \mathrm{M} \mathrm{HOBt}$ (1-hydroxybenzotriazole). A typical coupling cycle used 5 equiv of Fmoc-protected amino acid and 5 equiv of coupling reagent. Residues $1-5$ and 9 were double coupled. After synthesis, the resin was transferred from the reaction vessel to an Econo-Pac column (BioRad), washed with DMF and DCM, and dried under vacuum. Subsequently, 12.5 $\mathrm{mL}$ of cleavage solution (90\% TFA, $2.5 \% \mathrm{H}_{2} \mathrm{O}, 2.5 \%$ triisopropylsilane, $5 \% \beta$-mercaptoethanol) was added to the resin. The cleavage reaction was stirred for 4 hours under room temperature. The vessel was drained, the resin rinsed with TFA several times and combined with the filtrate. The combined TFA solution was concentrated by evaporation to around $2.5 \mathrm{~mL}$ under a stream of $\mathrm{N}_{2}$. Then $30 \mathrm{~mL}$ of ice-cold diethyl ether was added to precipitate the peptide, which was collected by centrifugation $(4,000 \mathrm{~g}, 10 \mathrm{~min})$ and dried in a fume hood overnight, yielding $\sim 0.2 \mathrm{~g}$ of crude product.

\section{Purification of CanA-core peptide}

Crude 14mer CanA core peptide was dissolved in $8 \mathrm{~mL}$ of $50 \%$ acetonitrile and purified on an Agilent 1260 Infinity preparative HPLC system equipped with a photodiode array detector and an automated fraction collector. The sample was repeatedly injected onto a preparative Luna C18 column (Phenomenex, $5 \mu \mathrm{m}, 21.2 \times 250 \mathrm{~mm}$ ) operating at a flow rate of $12 \mathrm{~mL} / \mathrm{min}$ with mobile phases of water and acetonitrile $(+0.1 \%$ formic acid). Elution was carried out isocratically at $30 \% \mathrm{MeCN}$ for $5 \mathrm{~min}$, followed by a gradient of 30-65\% MeCN over $15 \mathrm{~min}$. Fractions containing the CanA core peptide, as detected by HPLC-MS analysis, were pooled and lyophilized to dryness, yielding $15 \mathrm{mg}$ of pure CanA core peptide.

\section{ITC experiments}

Protein samples were buffer exchanged into a glycerol-free buffer $(25 \mathrm{mM}$ Tris, $100 \mathrm{mM}$ $\mathrm{NaCl}, \mathrm{pH}$ 7.7) using desalting columns (Zeba ${ }^{\mathrm{TM}}$ Spin Desalting Column). ITC was performed on a MicroCal PEAQ-ITC system (Malvern) at $25^{\circ} \mathrm{C}, 750 \mathrm{rpm}$. The concentration of CanB1 solution was $\sim 60 \mu \mathrm{M}$, and GS-CanA, NusA-CanA, NusA-CanA(D14E), NusA-CanA(D14N), or the CanA core peptide solution was diluted to $\sim 5 \mu \mathrm{M}$. Analyte solutions were loaded into a sample cell and titrated with CanB1 solutions in the syringe. An initial injection of $0.4 \mu \mathrm{L}$ was followed by 19-time injections of $2 \mu \mathrm{L}$ at $0.5 \mu \mathrm{L} / \mathrm{s}$ with intervals of $150 \mathrm{~s}$. Data were processed and analyzed in MicroCal PEAQ-ITC Analysis Software. 
Table S1. Primers used in this study. Restriction enzyme recognition sites are underlined.

\begin{tabular}{|c|c|}
\hline CanE_for & 5'- ATATATCATATGATGAAGATGACAGGACTGACGGAGTTCGG -3' \\
\hline CanE_rev & 5'- ATATATCTCGAGTCACGGCTCCCCGGCGATGGTGAT -3’ \\
\hline CanA_for & 5' - ATATATGGATCCATGTCGAATTCAGTGCACAACACTGACAGG -3' \\
\hline CanA_rev & 5'- ATATATCTCGAGTCAGTCGAAGTGGATGAAGAAGTCGGCC -3’ \\
\hline CanA_D14A_rev & 5'- GTGGTGGTGCTCGAGTCAGGCGAAGTGGATGAAGAAGTC -3' \\
\hline CanA_D14E_rev & 5'- GTGGTGGTGㅁTCGAGTCACTCGAAGTGGATGAAGAAGTC -3' \\
\hline CanA_D14N_rev & 5'- GTGGTGGTGCTCGAGTCAGTTGAAGTGGATGAAGAAGTC -3' \\
\hline CanA D14S_rev & 5'- GTGGTGGTGCTCGAGTCAGCTGAAGTGGATGAAGAAGTC -3' \\
\hline CanE KO L for & 5'- ATATATACTAGTCGCGTTCGGCCTCCATTCAGCGGC -3' \\
\hline CanE_KO_L_rev & 5' - ATATATGAATTCGGCGGGCCTGCGCAAGATCACCC -3' \\
\hline CanE_KO_R_for & 5'- ATATATAAGCTTGTCTGGAGCCGGATGCAGGGGTGGC -3' \\
\hline CanE_KO_R_rev & 5' - ATATATGGTACCCCGGAGGGCTGGACTCCACCCCC -3' \\
\hline CanC_KO_L_for & 5'- ATATATGAGCTCGGTGCCAGAAGGCCGTCGCCTGGG -3' \\
\hline CanC_KO_L_rev & 5' - ATATATTCTAGAGGGCCACCAAGGGGGAGTTCTCGG -3' \\
\hline CanC_KO_R_for & 5'- ATATATACTAGTACGGAGTGGACGCCCCGCACCAG -3' \\
\hline CanC_KO_R_rev & 5'- ATATATAAGCTTCCCCGCCAGGAGGATGCCGAAGCC -3' \\
\hline 773_for_Spel & 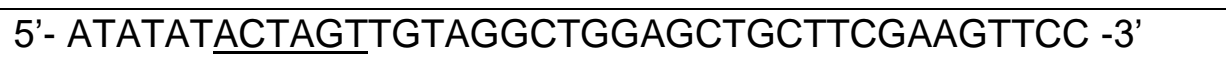 \\
\hline 773_rev_Spel & 5'- ATATATACTAGTATTCCGGGGATCCGTCGACCTGCAGTTC -3' \\
\hline CanE_KOcheck_L & 5'- GTCGTCGTGGACGAGCAGGAAGAGCC -3' \\
\hline CanE_KOcheck_R & 5'- CTGCTCGAGAAACTGCGGCACGCG -3' \\
\hline CanC_KOcheck_L & 5'- CGCCGATCCGGATGTCCGACTCACGG -3' \\
\hline CanC_KOcheck_R & 5’- GTGCCGCGCAGGAGGCTCGCGACGA -3' \\
\hline 773_KOcheck_R & 5'- GGCAGGATCGAACGGCTCGTCGTCCAG -3' \\
\hline 773_KOcheck_L & 5'- GGACTGATCGAGGCCCTGCGTGCTG -3' \\
\hline CanB1_for & 5'- ATATATCATATGGTGTCGATCACTCTGGCTGATGGCG -3' \\
\hline CanB1_rev & 5'- ATATATAAGCTTTCATGAGCTGACCAGACCCGCGTG -3' \\
\hline CanB2_for & 5'- ATATATGAATTCATGAGCACACCCGTCGCCCTC -3' \\
\hline CanB2_rev & 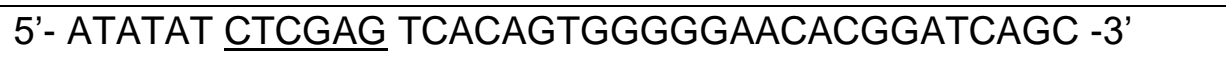 \\
\hline
\end{tabular}


Table S2. Observed and calculated $(\mathrm{m} / \mathrm{z})$ for CanE assays using NusA-CanA as substrate.

\begin{tabular}{ccccc}
\hline Peptide & $z$ & $(\mathrm{~m} / \mathrm{z})$ obs & $(\mathrm{m} / \mathrm{z})$ calc & $\delta(\mathrm{ppm})$ \\
\hline $\begin{array}{c}\text { CanA core } \\
\text { hydroxylated } \\
\text { CanA core }\end{array}$ & 2 & 791.3944 & 791.3905 & 4.9 \\
$\begin{array}{c}\text { CanA core D14E } \\
\text { hydroxylated }\end{array}$ & 2 & 799.3920 & 799.3880 & 5.0 \\
$\begin{array}{c}\text { CanA core D14E } \\
\text { CanA core D14N }\end{array}$ & 2 & 798.3984 & 798.3983 & 0.1 \\
hydroxylated & 2 & 790.8981 & 790.8985 & 0.5 \\
CanA core D14N & 2 & 798.8925 & 798.8960 & 4.4 \\
\hline
\end{tabular}


Table S3. Observed and calculated $(\mathrm{m} / \mathrm{z})$ for MS/MS fragments for the product of CanE/NusACanA reaction.

\begin{tabular}{|c|c|c|c|}
\hline Fragment & $(\mathrm{m} / \mathrm{z}) \mathrm{obs}$ & $(\mathrm{m} / \mathrm{z}) \mathrm{calc}$ & $\delta(\mathrm{ppm})$ \\
\hline $\mathrm{b} 2^{+}$ & 157.0973 & 157.0972 & 0.7 \\
\hline $\mathrm{b}^{+}$ & 214.1198 & 214.1187 & 5.5 \\
\hline b4 ${ }^{+}$ & 361.1847 & 361.1871 & 6.5 \\
\hline b5 ${ }^{+}$ & 458.2390 & 458.2398 & 1.9 \\
\hline $\mathrm{b} 6^{+}$ & 571.3251 & 571.3239 & 2.1 \\
\hline$b 7^{+}$ & 642.3631 & 642.3610 & 3.3 \\
\hline $\mathrm{b}^{+}$ & 757.3892 & 757.3880 & 1.7 \\
\hline b9+ & 904.4572 & 904.4564 & 0.9 \\
\hline b10 ${ }^{+}$ & 1051.5252 & 1051.5248 & 0.4 \\
\hline b11 + & 1164.6111 & 1164.6088 & 1.9 \\
\hline b12 ${ }^{+}$ & 1301.6690 & 1301.6678 & 0.9 \\
\hline $\mathrm{b} 13^{+}$ & 1448.7378 & 1448.7362 & 1.1 \\
\hline b14 $4^{+}$ & 1579.7588 & 1579.7580 & 0.5 \\
\hline $\mathrm{y}^{+}$ & 434.1672 & 434.1671 & 0.4 \\
\hline $\mathrm{y} 4^{+}$ & 547.2510 & 547.2511 & 0.3 \\
\hline$y 5^{+}$ & 694.3198 & 694.3195 & 0.4 \\
\hline$y 6^{+}$ & 841.3902 & 841.3880 & 2.7 \\
\hline$y 7^{+}$ & 956.415 & 956.4149 & 0.5 \\
\hline $\mathrm{y}^{+}$ & 1027.4521 & 1027.4520 & 0.1 \\
\hline $\mathrm{y}^{1} 0^{+}$ & 1237.5918 & 1237.5888 & 2.4 \\
\hline $\mathrm{y} 11^{+}$ & 1384.6554 & 1384.6572 & 1.3 \\
\hline $\mathrm{y} 12^{+}$ & 1441.6820 & 1441.6787 & 2.3 \\
\hline
\end{tabular}


Table S4. Observed and calculated $(\mathrm{m} / \mathrm{z})$ for CanE assays using GS-CanA as substrate.

\begin{tabular}{ccccc}
\hline Peptide & $z$ & $(\mathrm{~m} / \mathrm{z})$ obs & $(\mathrm{m} / \mathrm{z})$ calc & $\delta(\mathrm{ppm})$ \\
\hline \multirow{2}{*}{ GS-CanA } & {$[\mathrm{M}+4 \mathrm{H}]^{4+}$} & 1563.4625 & 1563.4653 & 1.8 \\
& {$[\mathrm{M}+3 \mathrm{H}+\mathrm{Na}]^{4+}$} & 1568.9658 & 1568.9608 & 3.2 \\
\hline $\begin{array}{c}\text { hydroxylated } \\
\text { GS-CanA }\end{array}$ & {$[\mathrm{M}+4 \mathrm{H}]^{4+}$} & 1567.4656 & 1567.4640 & 1.0 \\
\hline
\end{tabular}

Table S5. Observed and calculated $(\mathrm{m} / \mathrm{z})$ for MS/MS fragments for the product of CanE/NusACanA(D14E) reaction in the presence of CanB1.

\begin{tabular}{|c|c|c|c|}
\hline Fragment & $(m / z)$ obs & $(\mathrm{m} / \mathrm{z})$ calc & $\delta(p p m)$ \\
\hline $\mathrm{b}^{+}$ & 214.1189 & 214.1187 & 1.1 \\
\hline $\mathrm{b} 4^{+}$ & 361.1884 & 361.1871 & 3.5 \\
\hline$b 7^{+}$ & 642.3653 & 642.3610 & 6.6 \\
\hline b9 ${ }^{+}$ & 904.4572 & 904.4564 & 0.9 \\
\hline b10 & 1051.5255 & 1051.5248 & 0.7 \\
\hline $\mathrm{b} 12^{+}$ & 1301.6676 & 1301.6678 & 0.1 \\
\hline b13 ${ }^{+}$ & 1448.7480 & 1448.7362 & 8.2 \\
\hline $\mathrm{y}^{+}$ & 448.1845 & 448.1828 & 3.9 \\
\hline $\mathrm{y} 4^{+}$ & 561.2692 & 561.2668 & 4.3 \\
\hline$y 5^{+}$ & 708.3434 & 708.3352 & 11.6 \\
\hline$y 6^{+}$ & 855.4052 & 855.4036 & 1.8 \\
\hline$y 7^{+}$ & 970.4355 & 970.4306 & 5.1 \\
\hline$y 8^{+}$ & 1041.4709 & 1041.4677 & 3.1 \\
\hline y10+ & 1251.6054 & 1251.6045 & 0.7 \\
\hline $\mathrm{y} 12^{+}$ & 1455.6954 & 1455.6944 & 0.7 \\
\hline
\end{tabular}


Table S6. Observed and calculated $(\mathrm{m} / \mathrm{z})$ for MS/MS fragments for the product of CanE/NusA$\mathrm{CanA}(\mathrm{D} 14 \mathrm{~N})$ reaction in the presence of CanB1.

\begin{tabular}{|c|c|c|c|}
\hline Fragment & $(\mathrm{m} / \mathrm{z})$ obs & $(\mathrm{m} / \mathrm{z})$ calc & $\delta(\mathrm{ppm})$ \\
\hline $\mathrm{b} 6^{+}$ & 571.3232 & 571.3239 & 1.2 \\
\hline $\mathrm{b} 8^{+}$ & 757.3833 & 757.3880 & 6.1 \\
\hline $\mathrm{b} 9^{+}$ & 904.4603 & 904.4564 & 4.4 \\
\hline $\mathrm{b} 10^{+}$ & 1051.5202 & 1051.5248 & 4.4 \\
\hline $\mathrm{b} 11^{+}$ & 1164.6122 & 1164.6089 & 2.8 \\
\hline b12+ & 1301.6733 & 1301.6678 & 4.3 \\
\hline $\mathrm{b} 13^{+}$ & 1448.7357 & 1448.7362 & 0.4 \\
\hline b14 ${ }^{+}$ & 1578.7825 & 1578.7740 & 5.4 \\
\hline$y 3^{+}$ & 433.1888 & 433.1831 & 13.2 \\
\hline $\mathrm{y} 4^{+}$ & 546.2760 & 546.2671 & 16.2 \\
\hline$y 5^{+}$ & 693.3434 & 693.3355 & 11.3 \\
\hline$y 6^{+}$ & 840.4072 & 840.4039 & 3.9 \\
\hline$y 7^{+}$ & 955.4373 & 955.4309 & 6.8 \\
\hline$y 8^{+}$ & 1026.4646 & 1026.4680 & 3.4 \\
\hline $\mathrm{y} 10^{+}$ & 1236.6078 & 1236.6048 & 2.4 \\
\hline $\mathrm{y} 12^{+}$ & 1440.6894 & 1440.6947 & 3.7 \\
\hline
\end{tabular}


Figure S1. PCR verification of the S. canus canC::apr mutant. (A) Two pairs of primers were used, as shown, to verify insertion of apr gene (orange) in place of canC (blue). (B) Agarose gel of the amplified CanC_KOcheck_L/773_KOcheck_L fragment and the 773_KOcheck_L/ 773_KOcheck_R fragment show these to be present in canC::apr but not in wt.

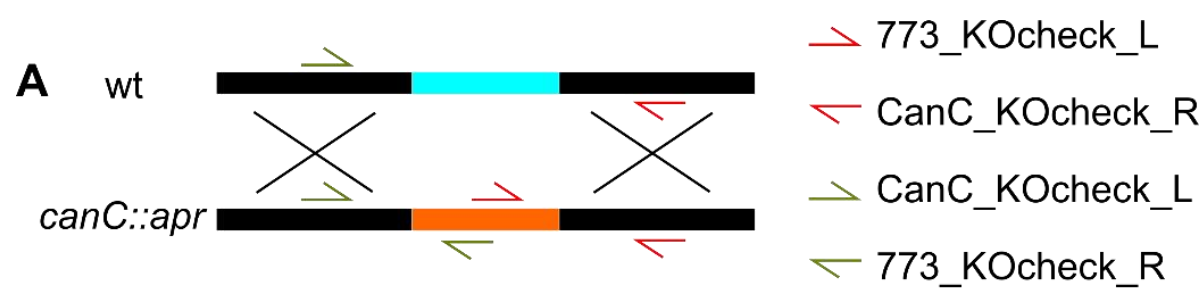

B

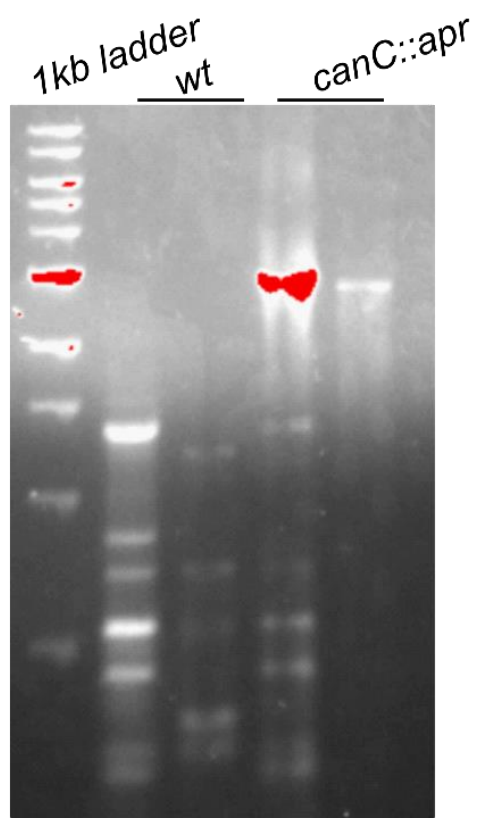


Figure S2. PCR verification of the S. canus canE::apr mutant. (A) One primer pair was used, as shown, to verify insertion of apr gene (orange) in place of canE (blue). (B) Agarose gel of the amplified fragment shows it to be present in canE::apr, but not in wt.

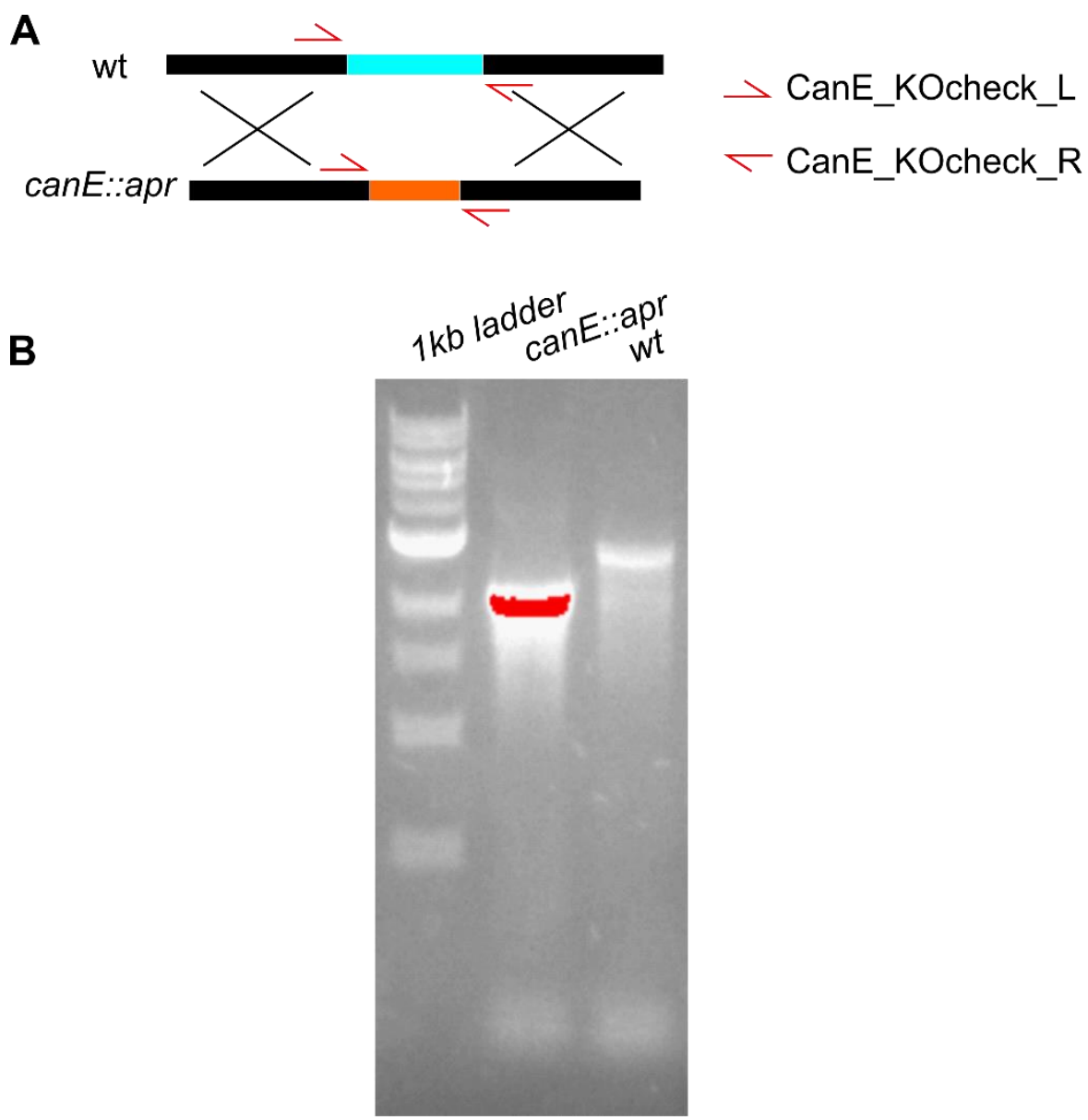


Figure S3. Substrate and hydroxylated product extracted ion chromatograms in CanE assays using canucin B as substrate.

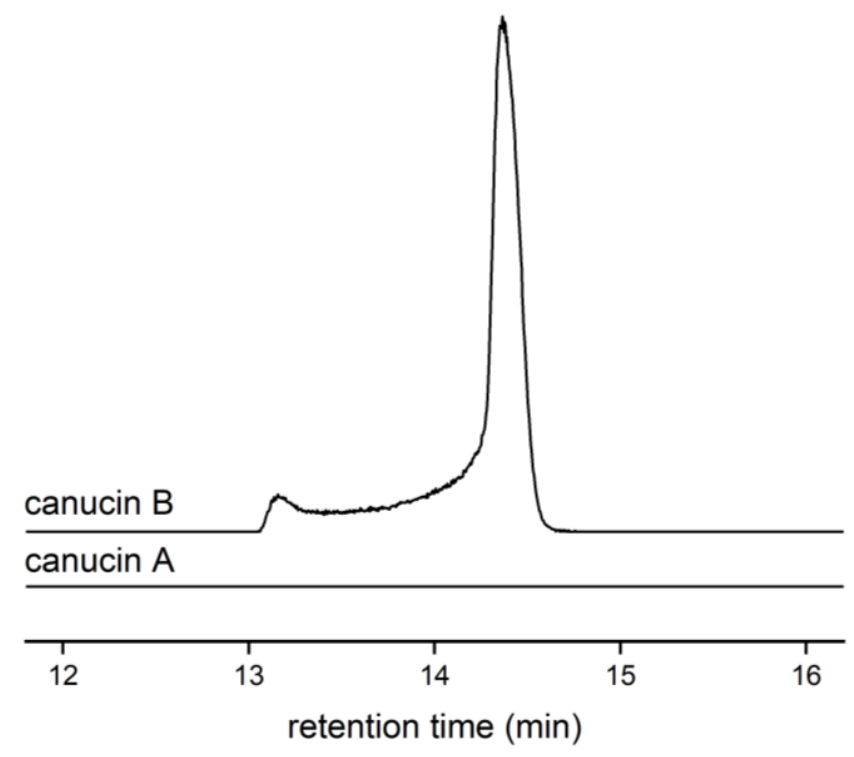

Figure S4. Tandem MS data for the product of CanE assays using NusA-CanA as substrate. The core peptide was liberated by trypsin digestion before tandem HR-MS analysis. Fragments are marked on the spectrum. Data are summarized below the spectrum.

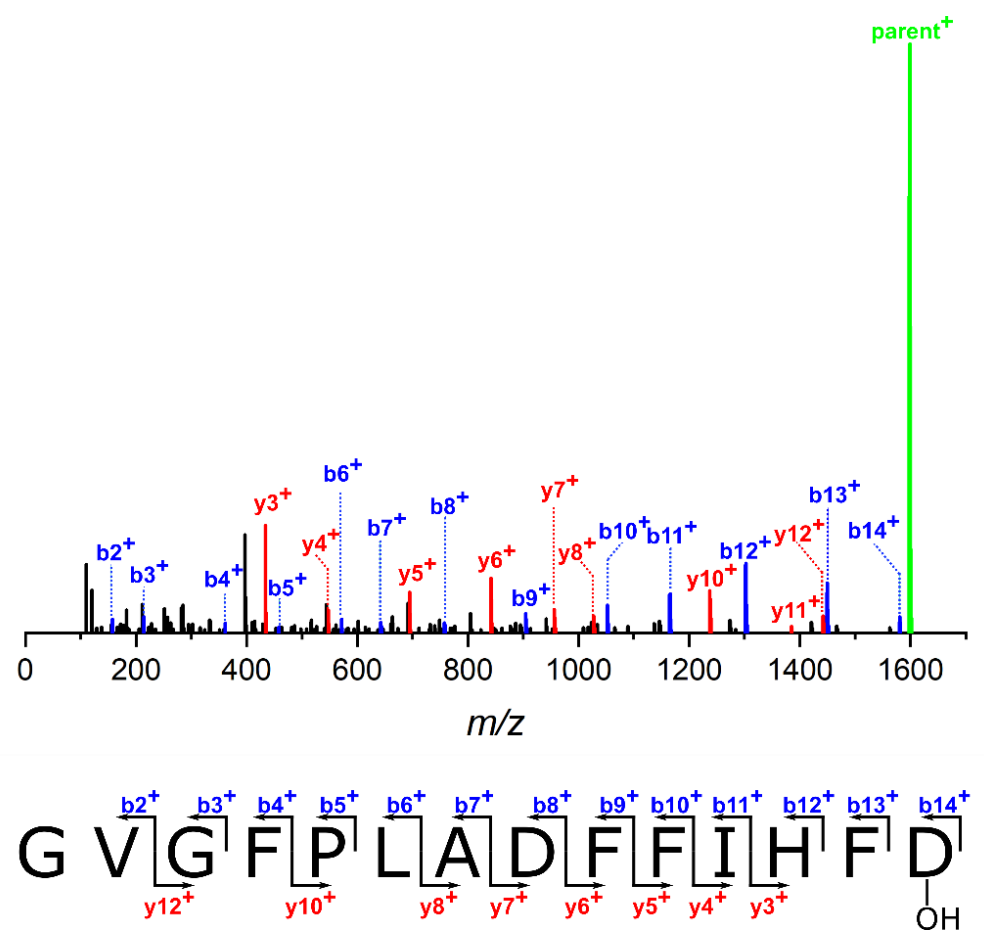


Figure S5. HPLC-QToF-HRMS analysis of the product of CanE assays using GS-CanA as substrate. Shown are product spectra for the full reaction (top) and for the control reaction lacking a-KG (bottom).

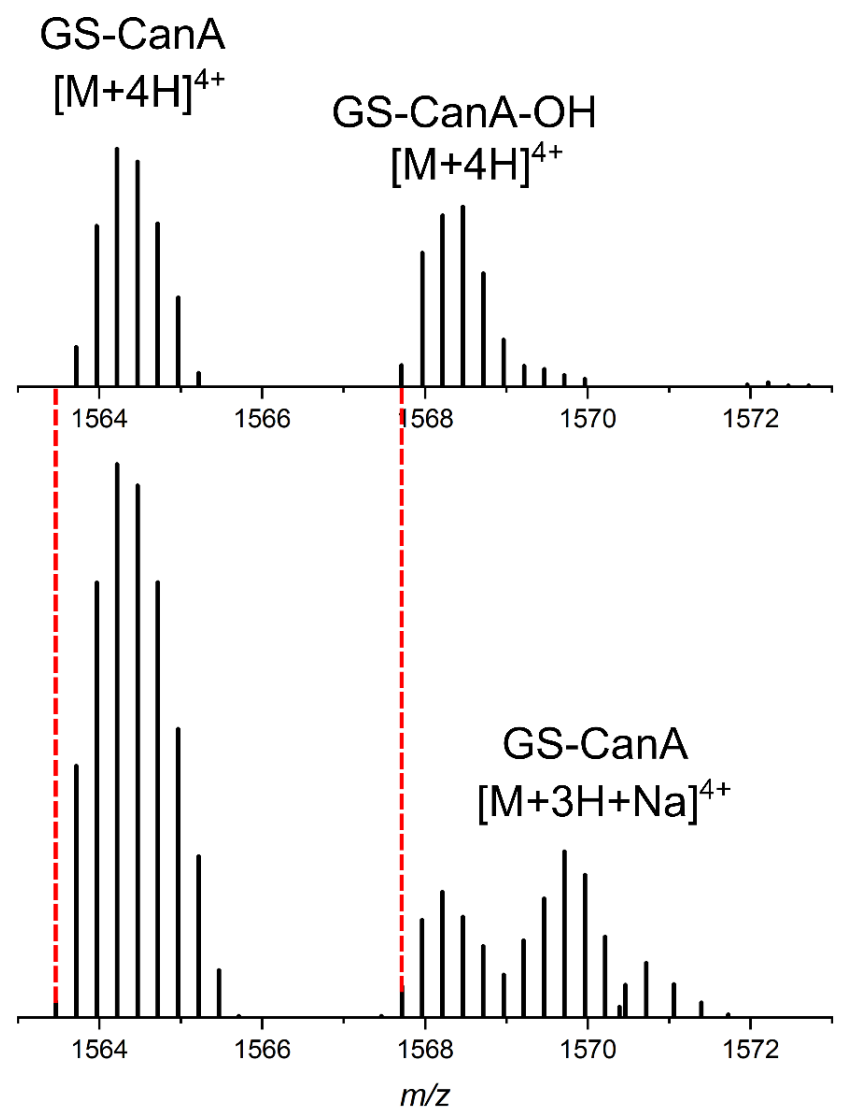


Figure S6. ITC binding curve of NusA-CanA(D14E) to CanB1. Line represents fits to the data using a one-to-one binding model and gives a $K_{\mathrm{d}}$ of $99 \pm 38 \mathrm{nM}$.

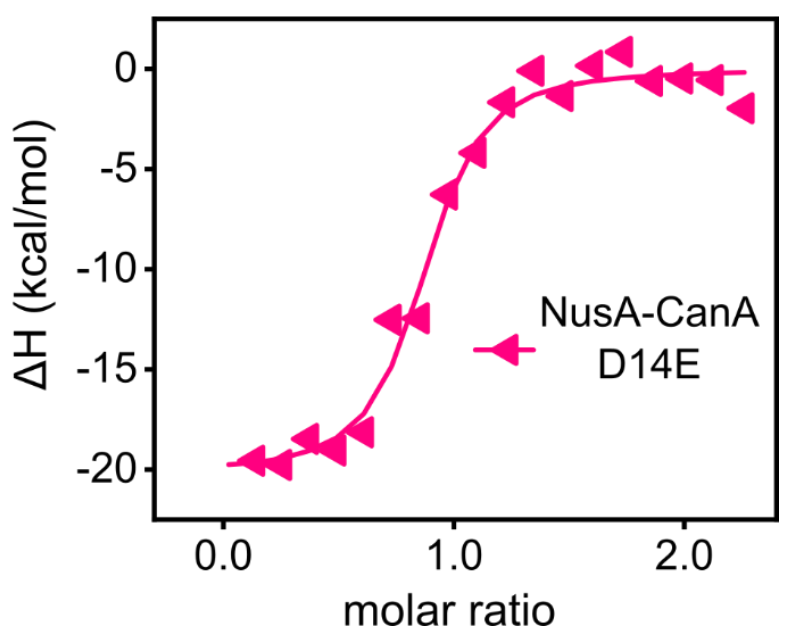

Figure S7. ITC binding curve of NusA-CanA(D14N) to CanB1. Line represents fits to the data using a one-to-one binding model and gives a $K_{d}$ of $106 \pm 21 \mathrm{nM}$.

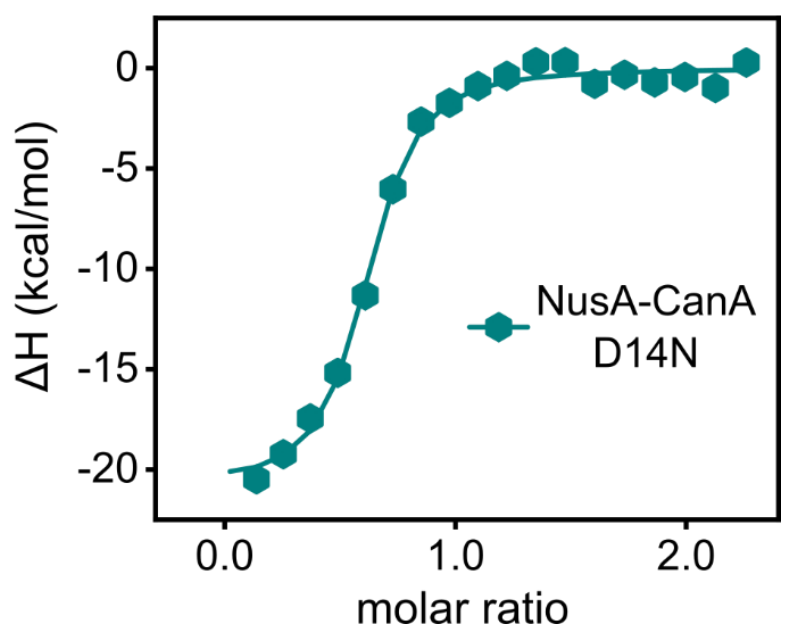


Figure S8. HPLC-MS analysis of the reaction of CanB2 wtih NusA-CanA. Shown are extracted ion chromatograms of the product (CanA core peptide, $m / z=791.4, z=2$ ) in the full reaction and in control reactions lacking CanB1 or with heat-inactivated CanB2.

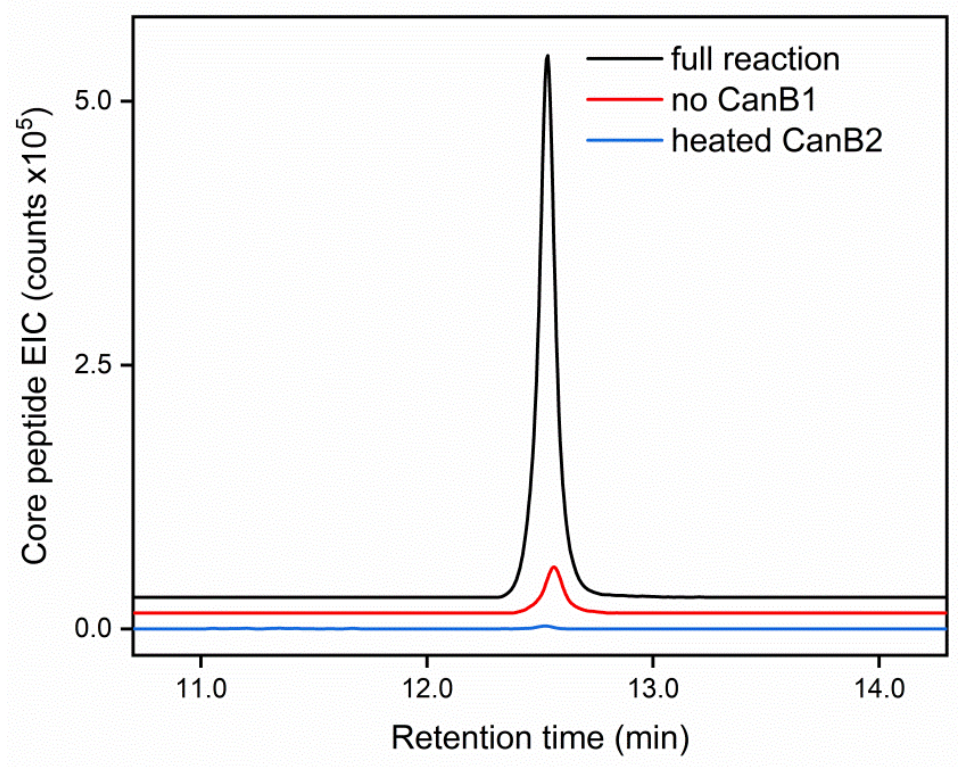

Figure S9. HPLC-MS analysis pf the reaction of CanE using NusA-CanA(D14E) as substrate in the absence (left) or presence (right) of CanB1. Shown are extracted ion chromatograms for the substrate $(m / z=798.4, z=2)$ and product $(m / z=806.4, z=2)$.

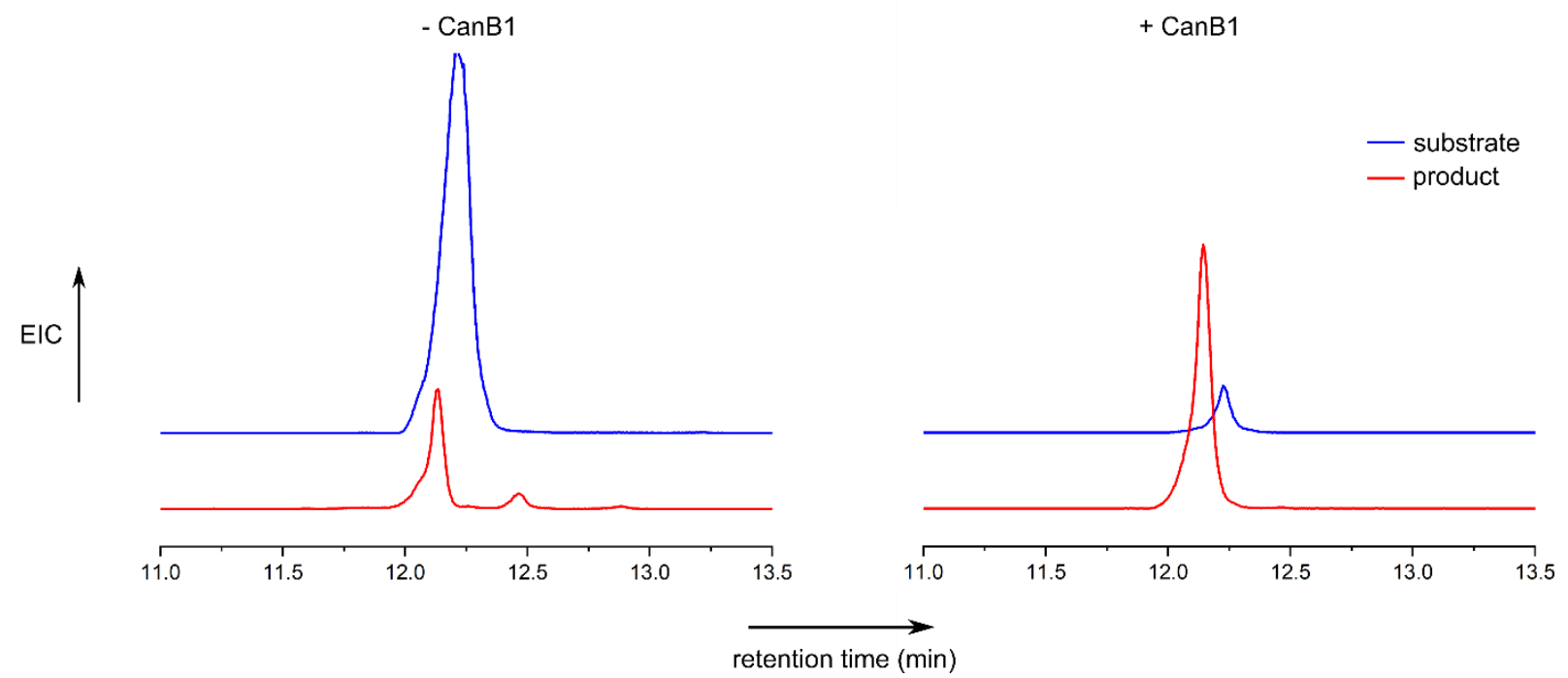


Figure S10. HPLC-MS analysis for the reaction of CanE using NusA-CanA(D14N) as substrate in the absence (left) or presence (right) of CanB1. Shown are extracted ion chromatograms for the substrate $(\mathrm{m} / \mathrm{z}=790.9, \mathrm{z}=2)$ and product $(\mathrm{m} / \mathrm{z}=798.9, \mathrm{z}=2)$.

- CanB1

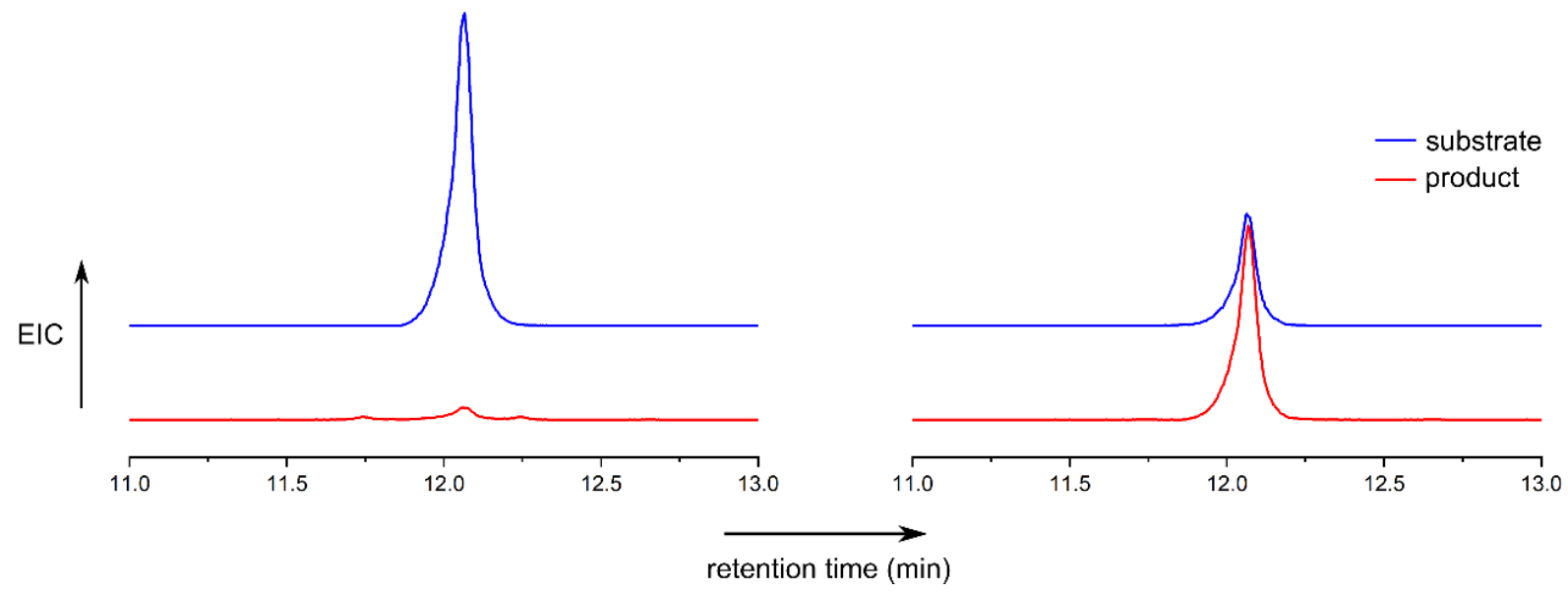

Figure S11. Tandem MS data for the product of CanE assays, in the presence of CanB1, using NusA-CanA(D14E) as substrate. The core peptide was liberated by trypsin digestion before tandem HR-MS analysis. Fragments are marked on the spectrum. Data are summarized below the spectrum.

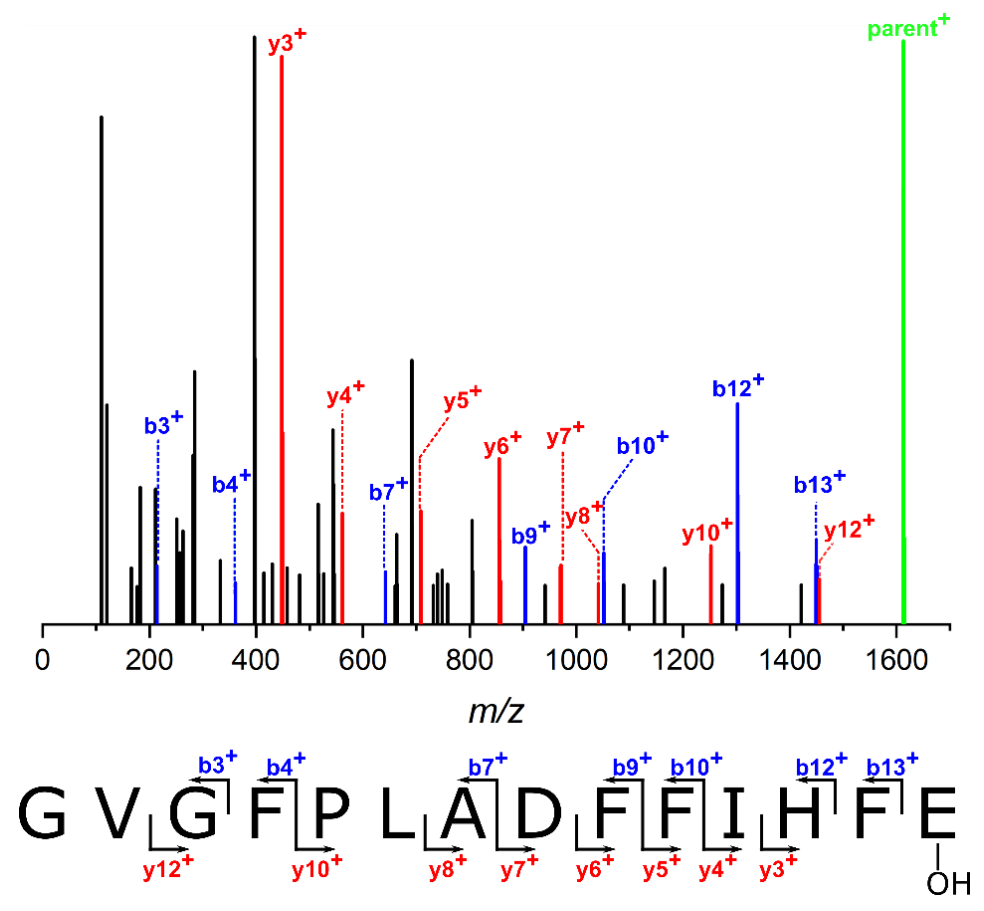


Figure S12. Tandem MS data for the product of CanE assays, in the presence of CanB1, using NusA-CanA(D14N) as substrate. The core peptide was liberated by trypsin digestion before tandem HR-MS analysis. Fragments are marked on the spectrum. Data are summarized below the spectrum.

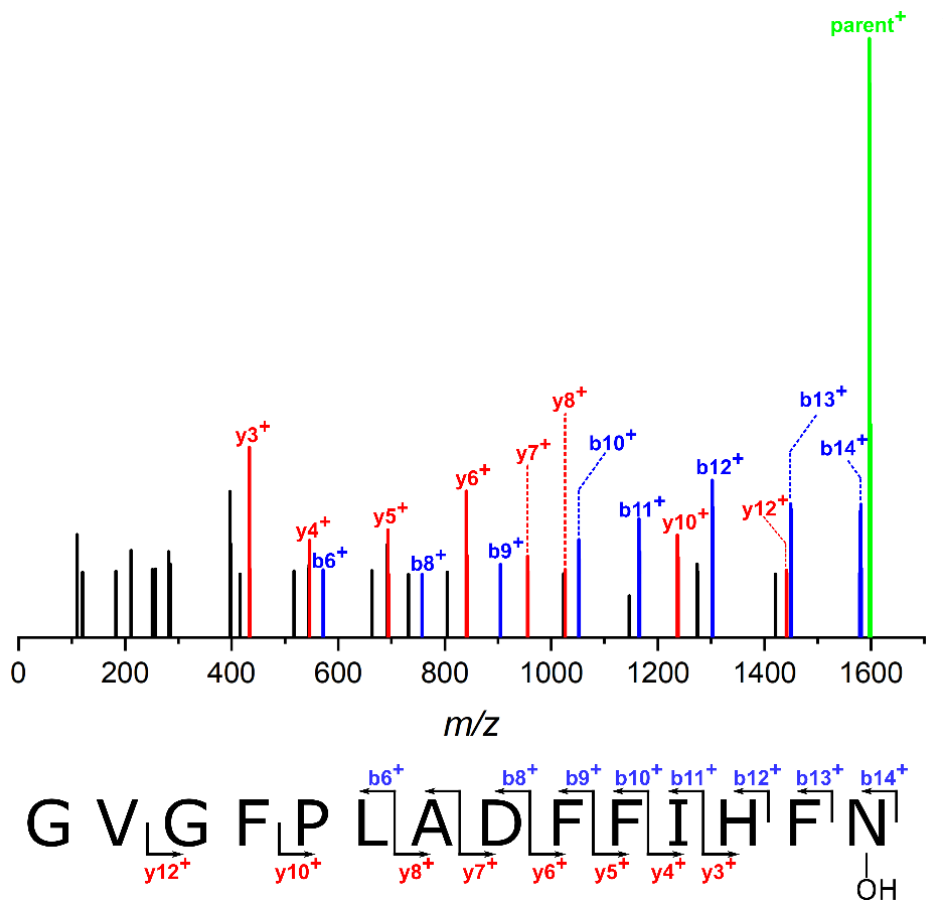

Figure S13. HPLC-MS analysis of the reaction of CanE using core CanA as substrate in the absence (left) or presence (right) of CanB1. Shown are extracted ion chromatograms for the substrate $(m / z=790.9, z=2)$ and product $(m / z=798.9, z=2)$.
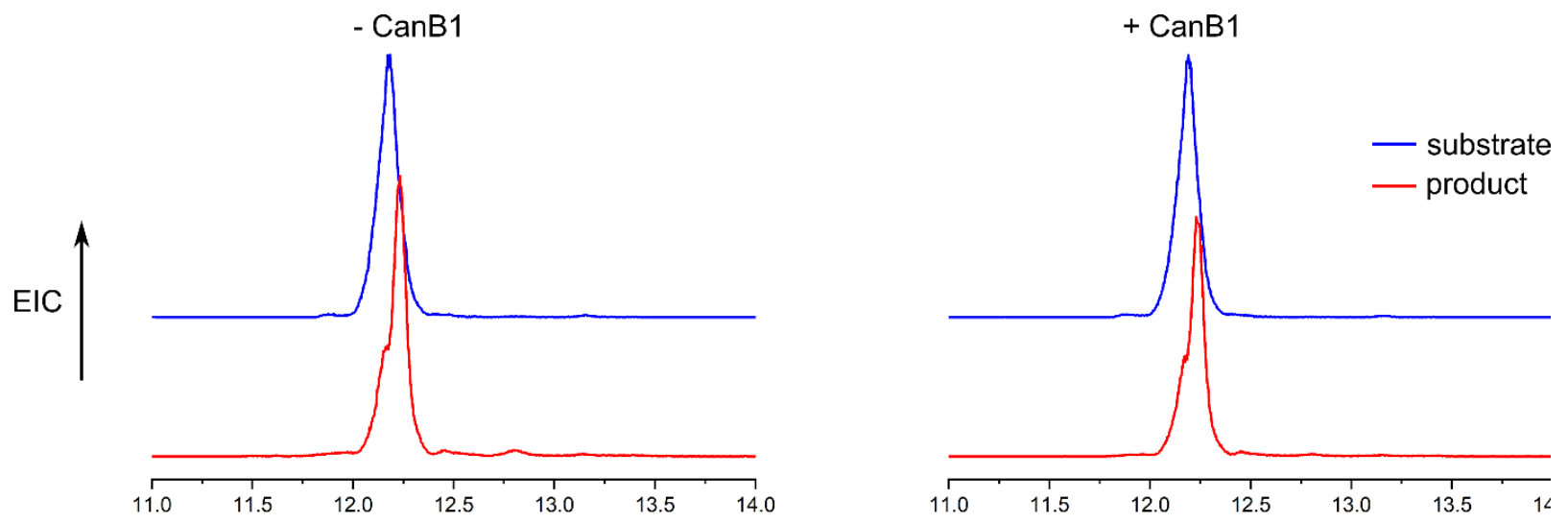

retention time ( $\mathrm{min})$ 